\title{
The survivin -31 snp in human colorectal cancer correlates with survivin splice variant expression and improved overall survival
}

\author{
Anna G. Antonacopoulou ${ }^{a}$, Konstantina Floratou ${ }^{\text {a }}$, Vasiliki Bravou ${ }^{\text {a,b }}$, Anastasia Kottorou ${ }^{\text {a }}$, \\ Fotinos-Ioannis Dimitrakopoulos ${ }^{a}$, Stella Marousi ${ }^{a}$, Michalis Stavropoulos ${ }^{c}$, Agelos K. Koutras ${ }^{\text {a }}$, \\ Chrisoula D. Scopa ${ }^{\mathrm{d}}$ and Haralabos P. Kalofonos ${ }^{\mathrm{a}, *}$ \\ a Molecular Oncology Laboratory, Medical School, University of Patras, Rion, Greece \\ ${ }^{\mathrm{b}}$ Department of Anatomy-Histology-Embryology, Medical School, University of Patras, Rion, Greece \\ ${ }^{\mathrm{c}}$ Department of Surgery, Medical School, University of Patras, Rion, Greece \\ ${ }^{\mathrm{d}}$ Department of Pathology, Medical School, University of Patras, Rion, Greece
}

\begin{abstract}
Background: Survivin is involved in the regulation of cell division and survival, two key processes in cancer. The majority of studies on survivin in colorectal cancer (CRC) have focused on protein expression and less is known about the expression of survivin splicing variants or survivin gene polymorphisms in CRC. In the present study, the mRNA levels of the five known isoforms of survivin as well as survivin protein were assessed in matched normal and neoplastic colorectal tissue. Moreover, the $9386 \mathrm{C} / \mathrm{T}$ and $-31 \mathrm{G} / \mathrm{C}$ polymorphisms were investigated.

Methods: Quantitative RT-PCR was used to assess mRNA levels in fresh/frozen tissue samples. Protein levels were immunohistochemically evaluated on formalin-fixed paraffin-embedded tissue sections. Individuals were genotyped using real time PCR.

Results: Expression of all 5 survivin splice variants as well as survivin protein was elevated in colorectal carcinomas compared to normal tissue. Specific splice variant expression differentially correlated with clinicopathological parameters. Furthermore, both snps correlated with splice variant levels or their ratios in colorectal carcinomas while the $-31 \mathrm{G} / \mathrm{C}$ snp may be related to CRC development and improved overall survival.

Conclusion: Our results support a role of survivin in colorectal carcinogenesis while the $-31 \mathrm{G} / \mathrm{C}$ snp may constitute a marker of survival.
\end{abstract}

Keywords: Survivin, splice variant, polymorphism, colorectal cancer, survival

\section{Introduction}

Survivin is a unique member of the family of the Inhibitors of Apoptosis Proteins (IAPs) as it carries a single baculoviral IAP repeat (BIR) domain. Survivin has lately drawn much attention due to its involvement in many cellular processes. It functions as a central regulator of cell division as it has been shown to promote mitotic progression and G1/S transition in cancer cells $[19,20]$. Survivin also exerts significant antiapoptotic functions via caspase-dependent and inde-

\footnotetext{
${ }^{*}$ Corresponding author: Haralabos P. Kalofonos, Clinical Oncology Laboratory, Division of Oncology, Department of Medicine, Medical School, University of Patras, 26504 Rion, Patras, Greece. Tel.: +30 2610 999535; Fax: +30 2610 994645; E-mail: kalofon@med.upatras.gr.
}

pendent mechanisms [20]. Consistently, it is not expressed or is present at low levels in normal differentiated tissues, whereas it is highly expressed in many tumors including breast, lung and colon $[1,13,26,33]$. Survivin has also been correlated with chemoresistance [21].

Five splice variants that give rise to distinct survivin protein isoforms have been characterized (Fig. 1). Survivin-2B has a 23 aminoacid insertion between exon 2 and 3 causing a markedly reduced anti apoptotic potential [23]. Survivin- $\Delta$ Ex3 lacks exon 3 and has a different carboxy-terminal tail due to a frameshift in exon 4 but retains an anti-apoptotic activity [23]. In contrast, survivin-3B has an extra exon 3 , derived from part of intron 3 , that causes a frameshift resulting in a protein truncated by 22 amino acids that exerts cytoprotective functions $[3,15]$. The re- 


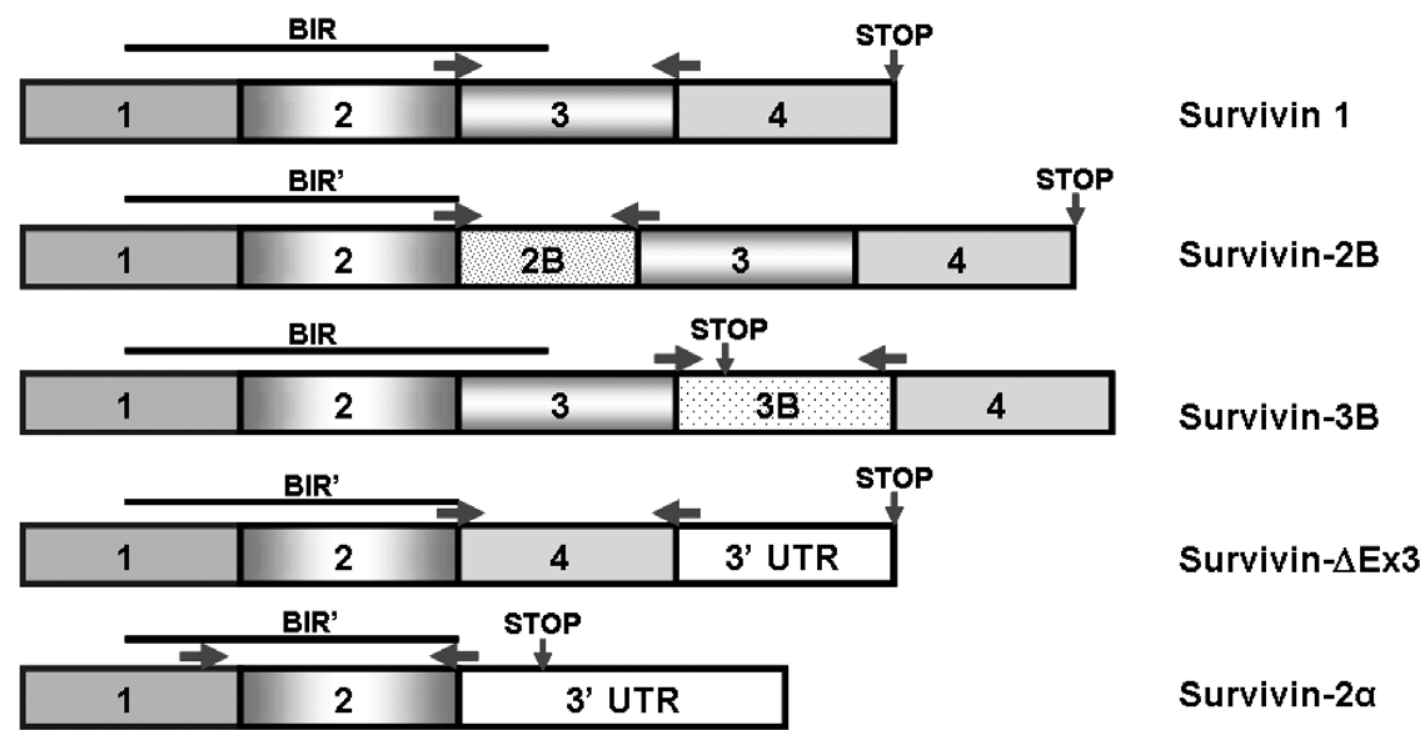

Fig. 1. The exons of the 5 splice variants of survivin. BIR: baculoviral IAP repeat, BIR': truncated BIR, UTR: Untranslated region. Horizontal arrows indicate primer positions. Perpendicular arrows indicated the site of the stop codon.

cently characterized isoform, survivin- $2 \alpha$, contains the coding sequences from exon 1 and exon 2 and one additional amino acid before termination. This protein isoform contains a truncated BIR domain and lacks the carboxy-terminal coiled-coil domain. It is, therefore, assumed that survivin- $2 \alpha$ does not exert anti-apoptotic activity [5]. Survivin is known to homodimerize in solution. Since survivin isoforms exert dinstinct apoptosis-related properties, heterodimer formation between survivin and its isoforms may be important in the regulation of survivin function with potential significant implications in carcinogenesis [19].

A single nucleotide polymorphism (snp) was found in the promoter of the survivin gene [36]. It is located at position -31 within a cell cycle-dependent element (CDE) and a cell cycle homology region (CHR) repressor binding motif. Modification of this binding motif results in altered cell cycle-dependent transcription that characterizes survivin expression. The presence of $-31 \mathrm{G} / \mathrm{C}$ snp may result in higher levels of survivin expression and it has previously been correlated with increased risk for lung cancer development. However, there was no correlation with cervical cancer suggesting that further investigation is required to clarify the significance of this polymorphism in human cancer $[4$, 10].

A second snp, 9386C/T (rs2239680), located in the $3^{\prime}$ untranslated region (UTR) of the survivin gene was selected from the National Center for Biotechnology
Information SNP database (http://www.ncbi.nlm.nih. gov/snp). It is known that many regulatory events occur at the $3^{\prime}$ UTR including mRNA stability and posttranscriptional regulation, often through binding of microRNAs [24].

Colorectal cancer is a major cause of morbidity and mortality worldwide. Alterations in pathways regulating important biological processes including cell survival, cell proliferation, epithelial to mesenchymal transition and stroma production have been shown to contribute to colorectal carcinogenesis and tumor progression [25,34]. Several lines of evidence suggest that survivin is implicated in the progression of dysplasia to neoplasia in the colon [14]. A significant role of survivin in colorectal carcinoma progression and recurrence of colon cancer liver metastases has been previously demonstrated [7,18]. However, most studies have focused on protein expression, and the significance of specific splice variant expression or of survivin gene polymorphisms in CRC has not been fully addressed. We, therefore, quantified the mRNA expression of survivin, survivin-3B, survivin-2B, survivin$\Delta \mathrm{Ex} 3$ and survivin- $2 \alpha$ in matched normal and neoplastic colorectal tissue. We also assessed the presence of the snps $9386 \mathrm{C} / \mathrm{T}$ and $-31 \mathrm{G} / \mathrm{C}$ of the survivin gene in blood samples and CRC tissues. Correlations between survivin splice variant mRNA expression, presence of survivin snps, survivin protein expression by immunohistochemistry and clinicopathological characteristics were evaluated. Moreover, the relationship between the 
$-31 \mathrm{G} / \mathrm{C}$ snp and the risk for CRC development was assessed.

\section{Materials and methods}

\subsection{Patients and samples}

Peripheral blood and fresh-frozen colonic tissue were prospectively obtained from 45 consecutive patients who underwent therapeutic surgery at the University Hospital of Patras, Greece. Table 1 lists the clinicopathological characteristics of the patients for which fresh/frozen samples were available for this study. Moreover, 116 formalin fixed paraffin-embedded colorectal carcinoma samples were retrieved from the archives of the Department of Pathology at the University Hospital of Patras. In addition, blood samples from 132 healthy donors were obtained. For 95 $(58.3 \%)$ patients information regarding relapse and survival was available. Of these, $53(55.8 \%)$ patients relapsed and the remaining $(44.2 \%)$ remained disease free. Ethical approval for this study was obtained from the Institutional Review Board.

\subsection{Primer design}

The sequence of each splice variant was obtained either from the National Centre for Biotechnology Infor-

Table 1

Patients' clinicopathological characteristics

\begin{tabular}{llc}
\hline Characteristic & & Patients (\%) \\
\hline Age median (range) & $68(56-86)$ & $45(100)$ \\
Gender & Male & $29(64.4)$ \\
& Female & $16(35.5)$ \\
Primary site & Right colon & $13(28.9)$ \\
& Left colon \& sigmoid & $18(40.0)$ \\
Stage (Astler-Coller) & Rectum & $14(31.1)$ \\
& In situ & $2(4.2)$ \\
& A & $1(2.1)$ \\
& B & $24(51.1)$ \\
& C & $15(31.9)$ \\
Lymph nodes & D & $3(6.4)$ \\
& Positive & $29(64.4)$ \\
Differentiation & Negative & $16(35.6)$ \\
& Poorly & $8(17.0)$ \\
& Moderately & $25(53.2)$ \\
& Well & $10(21.3)$ \\
\hline
\end{tabular}

mation (NCBI: http://www.ncbi.nlm.nih.gov/) or from published reports [3,5]. Regarding the gene expression analysis, primers and Taqman probes (Table 2) were designed at areas that were unique for each variant (Fig. 1), using Primer3 [29] and then subjected to a BLAST (NCBI) analysis to ensure specificity. Similarly, for the $-31 \mathrm{G} / \mathrm{C}$ snp genotyping, primers and Taqman LNA probes were designed, specific for each allele. The $9386 \mathrm{C} / \mathrm{T}$ snp was genotyped using allelespecific primers resulting in differentially sized products and thus allowing allele detection using sybr green in real time polymerase chain reactions (PCR) (Table 2). Primers were synthesized by the Foundation for Research and Technology-Hellas (Crete, Greece) or by Metabion International (Martinsried, Germany), Taqman probes by DNA Technology A/S (Aarhus C., Denmark) and LNA Taqman probes by Sigma-Proligo (The Woodlands, TX, USA).

\subsection{Splice variant expression quantification}

Total RNA was extracted from the fresh-frozen tissue samples using the Absolutely RNA ffpe kit (Stratagene, La Jolla, CA, USA) and then quantified and reverse transcribed as previously described [2]. The expression of each splice variant was quantified by quantitative PCR using the variant-specific primers and Taqman probes (Table 1) as previously described [9]. Expression levels were normalized to Alu-Sq levels that were found to be stably expressed in normal and tumor tissue of different grades and stages.

\subsection{Snp genotyping}

DNA was extracted from whole blood samples of 47 patients with CRC and 132 healthy controls using the QIAamp DNA blood mini kit (QIAGEN, GmbH, Germany). Moreover, DNA was extracted from 116 formalin-fixed paraffin embedded tissue samples using a standard proteinase $\mathrm{K}$, phenol/chloroform extraction procedure. The $-31 \mathrm{G} / \mathrm{C}$ snp was genotyped using the primers and allele-specific Taqman LNA probes (Table 2) in real time PCR reactions using the Brilliant Quantitative PCR Core Reagents (Stratagene) and the MX3000p (Stratagene). The 9386C/T snp was genotyped in 42 patients for which fresh-frozen tissue was also available using allele specific primers. A GC tail was added at the $5^{\prime}$ end of the C-specific primer so that different product sizes were obtained thus allowing genotyping using sybr green in real time PCR (sybr green master mix, PrimerDesign, UK) (Table 2). 
Table 2

Sequences of primers and probes

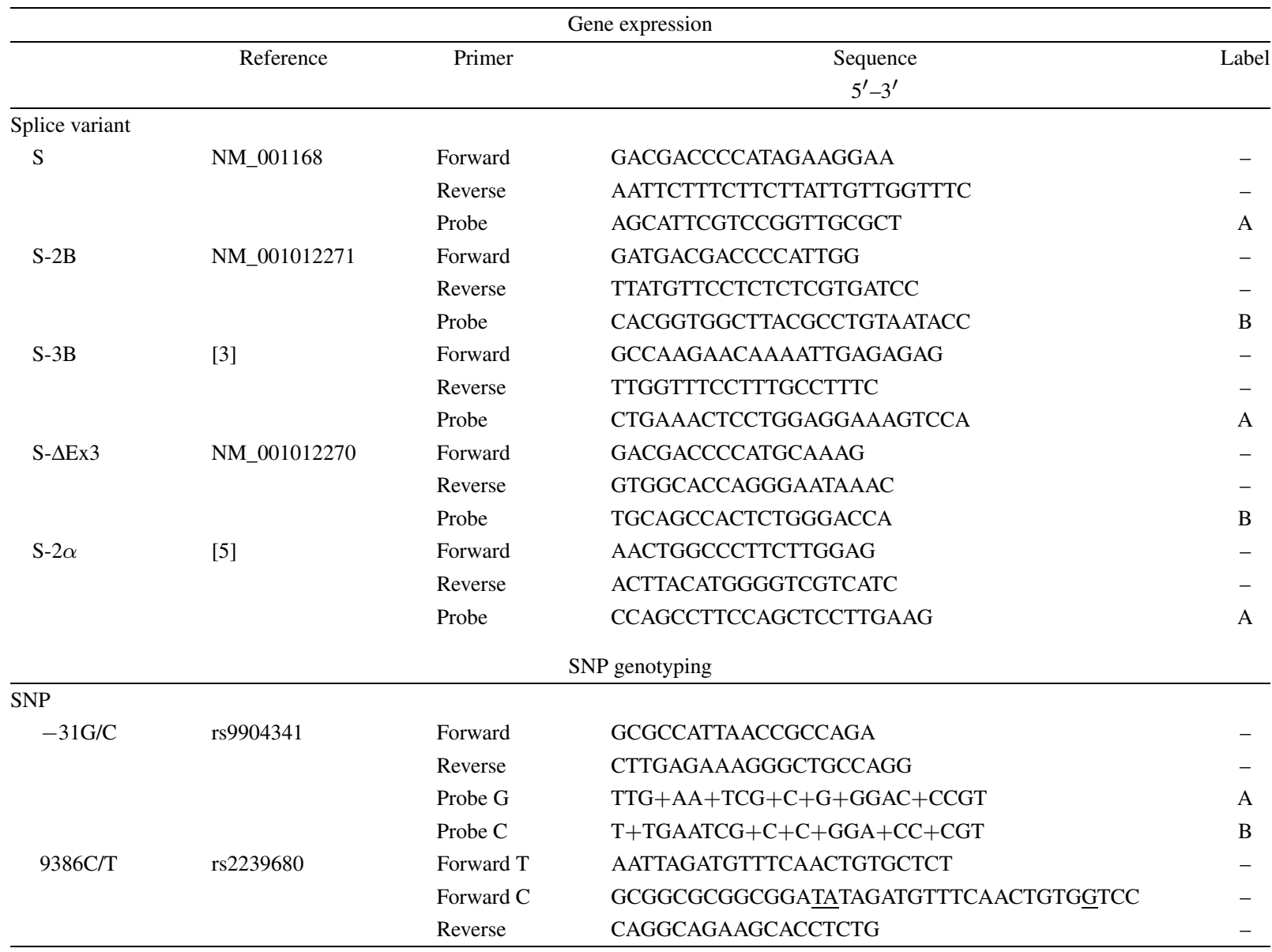

Notes: S - Survivin, A - 5' FAM, 3' BHQ1, B - 5' HEX, 3’ BHQ1, “+” before a base indicates a Locked Nucleic Acid base. Underlined are bases that are altered to increase specificity of the primer.

\subsection{Immunohistochemistry}

Representative $4 \mu \mathrm{m}$ tissue sections were de-paraffinized in xylene and rehydraded in graded ethanol solutions. Antigen retrieval was enhanced by microwaving the slides in $0.01 \mathrm{M}$ citrate buffer $(\mathrm{pH}=6)$. Endogenous peroxidase activity was blocked by treatment with $1 \%$ hydrogen peroxide for $15 \mathrm{~min}$, followed by incubation with protein blocking solution (3\% BSA in TBS). Sections were subsequently incubated with mouse monoclonal anti-survivin antibody (71G4B7E, Cell Signaling, Beverly, MA, USA) in dilution 1:80 overnight at $4^{\circ} \mathrm{C}$. Bound primary antibody was detected with the Envision detection kit (DAKO, Hamburg, Germany) following the manufacturer's instructions. Slides were counterstained with haematoxylin, dehydraded and mounted. For negative controls, blocking solution was added instead of the primary antibody.

\subsection{Immunohistological evaluation}

Nuclear and cytoplasmic immunostaining for survivin was evaluated separately. Nuclear expression of survivin was semi-quantitatively evaluated based on the percentage of positive nuclei: 0: nuclear positivity in less than $10 \%$ of tumor cells, 1: nuclear expression in $10-30 \%$ of tumor cells, 2 : nuclear expression in $30-80 \%$ of tumor cells and 3: nuclear expression in $>80 \%$ of tumor cells. Cytoplasmic immunoreactivity was homogeneously distributed among the tumor cells and scored as follows: 0: negative staining, 1: weak staining, 2: moderate staining and 3: strong staining.

\subsection{Statistical analysis}

The data were analysed using SPSS (release 16, Chicago, IL, USA). Kruskal-Wallis and Mann-Whit- 
ney nonparametric tests were performed for intergroup comparisons of the expression levels of the survivin splice variants. Wilcoxon paired samples test was used for comparisons between related groups. Chi-square analysis was performed to detect associations between snps and clinicopathological data. The Kaplan-Meier analysis was used to compare survival curves. Logistic regression was used for cancer risk assessment. The level of significance was set at $p$-value $<0.05$.

\section{Results}

\subsection{Expression of survivin splice variants in normal and neoplastic tissue}

Positive mRNA expression of all survivin isoforms was more frequently observed in neoplastic compared to normal tissue. In normal tissue, survivin, survivin$\Delta \mathrm{Ex} 3$, survivin-2 $\alpha$, survivin-2B and survivin-3B were expressed in $80.8,68.1,100,87.2$ and $78.7 \%$ of cases, respectively, whereas in neoplastic tissue, positive mRNA expression of theses variants was detected in $98.8,89.4,100,97.8$ and $95.7 \%$ of cases, respectively. In addition, expression levels of the five survivin splice variants were significantly higher in neo- plastic tissue compared to normal tissue $(p \leqslant 0.001)$, as shown in Tables 3 and 4 and Fig. 2.

No significant difference was observed in the expression levels between males and females and between patients with positive or negative lymph nodes. mRNA expression of survivin-2B significantly correlated with tumor grade with levels being higher in well differentiated compared to moderately and poorly differentiated tumors (Tables 3 and 4). A similar trend of higher expression in well differentiated tumors was also observed for survivin, survivin- $\Delta \mathrm{Ex} 3$ and survivin- $2 \alpha$ but the differences failed to reach statistical significance (Tables 3 and 4).

Survivin splice variants were differentially expressed among different stages of the disease (Tables 3 and 4). Statistical analysis could safely be performed only for stages B and C due to the small sample number of in situ and stage A and D samples. Therefore, it should be noted that only differences between stages $\mathrm{B}$ and $\mathrm{C}$ can be stated with any confidence. Survivin, survivin-2B and $-2 \alpha$ levels were lower in stage A than in $\mathrm{B}$. The mRNA expression levels of all splice variants with the exception of survivin-3B were also higher in stage $\mathrm{B}$ tumors compared to stage $\mathrm{C}$ (statistical significance was reached only for survivin- $\Delta \mathrm{Ex} 3,-2 \mathrm{~B}$ and $-2 \alpha$ with $p=0.008,0.028$ and 0.024 , respectively),

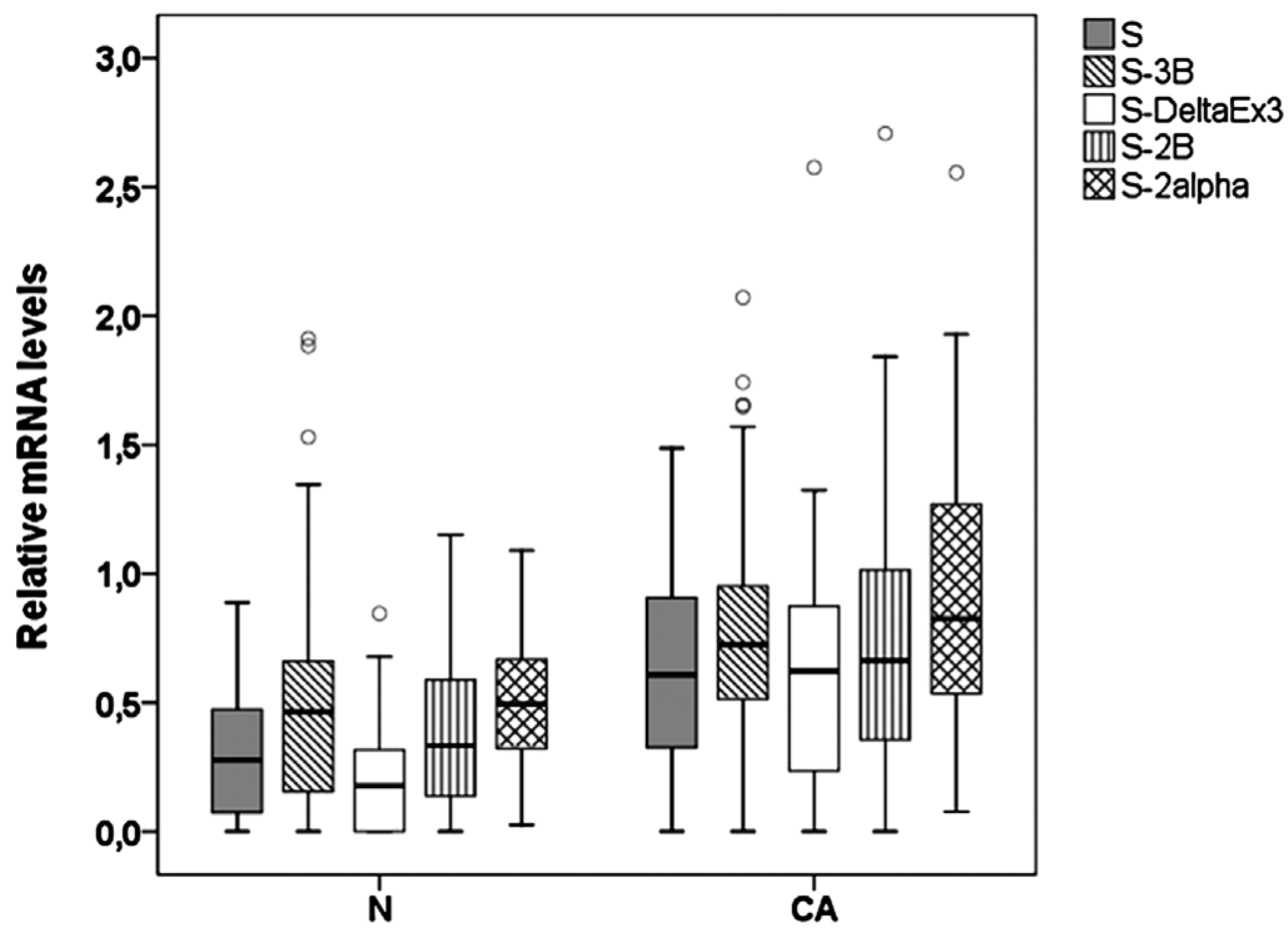

Fig. 2. Expression of survivin splice variants in normal and neoplastic tissue. $\mathrm{N}$ - normal tissue, $\mathrm{CA}$ - neoplastic tissue, $\mathrm{S}$ - survivin. 
Table 3

Expression of survivin splice variants survivin, survivin-3B and survivin- $\Delta$ Ex 3

\begin{tabular}{|c|c|c|c|c|c|c|c|}
\hline \multirow[t]{2}{*}{ Characteristic } & & \multicolumn{6}{|c|}{ Median relative expression (range) } \\
\hline & & $\mathrm{S}$ & $p$ & $\mathrm{~S}-3 \mathrm{~B}$ & $p$ & $\mathrm{~S}-\Delta \mathrm{Ex} 3$ & $p$ \\
\hline \multirow[t]{4}{*}{ Gender } & Male & 0.45 & \multirow{4}{*}{0.111} & 0.61 & & 0.53 & \multirow{4}{*}{0.298} \\
\hline & & $(0.07-1.49)$ & & $(0-1.74)$ & 0210 & $(0-2.57)$ & \\
\hline & Female & 0.63 & & 0.75 & 0.215 & 0.65 & \\
\hline & & $(0-1.33)$ & & $(0-2.07)$ & & $(0-1.32)$ & \\
\hline \multirow[t]{6}{*}{ Primary site } & Right colon & 0.58 & \multirow{6}{*}{0.456} & 0.75 & & 0.57 & \multirow{6}{*}{0.367} \\
\hline & & $(0-1.01)$ & & $(0-2.07)$ & & $(0-1.10)$ & \\
\hline & Left colon & 0.76 & & 0.73 & 0.652 & 0.68 & \\
\hline & and sigmoid & $(0.14-1.49)$ & & $(0.18-1.57)$ & & $(0-2.57)$ & \\
\hline & Rectum & 0.43 & & 0.66 & & 0.33 & \\
\hline & & $(0.07-1.22)$ & & $(0-0.65)$ & & $(0-1.12)$ & \\
\hline \multirow[t]{4}{*}{ Tissue } & $\mathrm{N}$ & 0.28 & \multirow{4}{*}{$<0.001$} & 0.46 & & 0.18 & \multirow{4}{*}{$<0.001$} \\
\hline & & $(0-0.89)$ & & $(0-1.91)$ & I $\cap 0 \cap$ & $(0-0.84)$ & \\
\hline & $\mathrm{Ca}$ & 0.61 & & 0.72 & 0.001 & 0.62 & \\
\hline & & $(0-1.49)$ & & $(0-2.07)$ & & $(0-2.57)$ & \\
\hline \multirow[t]{9}{*}{ Stage (Astler-Coller) } & In situ & 0.24 & & 0.22 & & 0.14 & \\
\hline & & $(0.14-0.32)$ & & $(0-0.66)$ & & $(0-0.31)$ & \\
\hline & A & 0.48 & & 0.81 & & 0.53 & \\
\hline & B & 0.73 & & 0.74 & & 0.69 & \\
\hline & & $(0.15-1.33)$ & 0.131 & $(0.18-1.74)$ & 0.521 & $(0.14-1.32)$ & 0.008 \\
\hline & $\mathrm{C}$ & 0.48 & $(\mathrm{~B}-\mathrm{C})$ & 0.66 & $(\mathrm{~B}-\mathrm{C})$ & 0.37 & $(\mathrm{~B}-\mathrm{C})$ \\
\hline & & $(0-1.22)$ & & $(0-2.07)$ & & $(0-0.97)$ & \\
\hline & $\mathrm{D}$ & 0.89 & 0.039 & 0.93 & 0.250 & 0.94 & 0.010 \\
\hline & & $(0.79-1.49)$ & (C-D) & $(0.82-1.32)$ & $(\mathrm{C}-\mathrm{D})$ & $(0.78-2.57)$ & $(\mathrm{C}-\mathrm{D})$ \\
\hline \multirow[t]{4}{*}{ Lymph nodes } & Positive & 0.53 & \multirow{4}{*}{0.403} & 0.72 & 0.902 & 0.46 & \multirow{4}{*}{0.115} \\
\hline & & $(0-1.49)$ & & $(0-2.07)$ & & $(0-2.57)$ & \\
\hline & Negative & 0.73 & & 0.75 & & 0.66 & \\
\hline & & $(0.15-1.33)$ & & $(0.18-1.74)$ & & $(0.14-1.32)$ & \\
\hline \multirow[t]{6}{*}{ Differentiation } & Well & 0.76 & & 0.79 & & 0.69 & \multirow{6}{*}{0.269} \\
\hline & & $(0.26-1.33)$ & & $(0.51-1.18)$ & & $(0.27-1.32)$ & \\
\hline & Moderately & 0.54 & 0.577 & 0.61 & 0.482 & 0.66 & \\
\hline & & $(0.07-1.49)$ & & $(0.12-1.74)$ & & $(0-2.57)$ & \\
\hline & Poorly & 0.53 & & 0.77 & & 0.55 & \\
\hline & & $(0-0.97)$ & & $(0-2.07)$ & & $(0-1.04)$ & \\
\hline
\end{tabular}

Notes: $\mathrm{S}$ - Survivin, $\mathrm{N}$ - normal tissue, $\mathrm{Ca}$ - tumor tissue.

and in stage D tumors compared to stage $\mathrm{C}$ ( $p$-values for survivin, survivin- $\Delta \mathrm{Ex} 3,-2 \mathrm{~B}$ and $-2 \alpha$ are 0.039 , $0.010,0.027$ and 0.017 , respectively).

\subsection{Ratios of splice variant expression in normal and neoplastic tissue}

The ratios of the expression of the different splice variants were then assessed. The expression ratio survivin to survivin-3B was significantly higher ( $p=$ 0.005 ) in neoplatic (median: $0.95 ; 0.31-1.93$ ) com- pared to normal tissue (median: $0.72 ; 0-1.91$ ) (Fig. 3A).

Moreover, the ratio of survivin to survivin- $\Delta \mathrm{Ex} 3$ was significantly higher ( $p=0.043)$ in the rectum samples (median: 1.48; 0.65-3.19) compared to left and right colonic tissue samples (median: 1.03 ; 0.45-1.78) although a similar difference was not noted for any other ratio. None of the ratios differed between lymph node positive or negative patients, or between different stages. However, the ratio of survivin to survivin2B expression was significantly higher $(p=0.038)$ 
Table 4

Expression of survivin splice variants survivin-2B and survivin-2 $\alpha$

\begin{tabular}{|c|c|c|c|c|c|}
\hline \multirow[t]{2}{*}{ Characteristic } & & \multicolumn{4}{|c|}{ Median relative expression (range) } \\
\hline & & S-2B & $p$ & $\mathrm{~S}-2 \alpha$ & $p$ \\
\hline \multirow[t]{4}{*}{ Gender } & Male & 0.55 & & 0.68 & \\
\hline & & $(0.08-2.71)$ & & $(0.08-2.56)$ & \\
\hline & Female & 0.88 & 0.330 & 1.08 & 0.156 \\
\hline & & $(0-1.84)$ & & $(0.29-1.73)$ & \\
\hline \multirow[t]{6}{*}{ Primary site } & Right colon & 0.55 & & 0.74 & \\
\hline & & $(0-1.38)$ & & $(0.32-1.39)$ & \\
\hline & Left colon & 0.88 & 0.162 & 1.13 & 0.391 \\
\hline & and sigmoid & $(0.20-2.71)$ & & $(0.19-2.56)$ & \\
\hline & Rectum & 0.48 & & 0.68 & \\
\hline & & $(0.09-1.84)$ & & $(0.08-1.73)$ & \\
\hline \multirow[t]{4}{*}{ Tissue } & $\mathrm{N}$ & 0.33 & & 0.49 & \\
\hline & & $(0-1.15)$ & & $(0.03-1.09)$ & \\
\hline & $\mathrm{Ca}$ & 0.66 & $<0.001$ & 0.82 & $<0.001$ \\
\hline & & $(0-2.71)$ & & $(0.08-2.56)$ & \\
\hline Stage & In situ & 0.22 & & 0.38 & \\
\hline \multirow[t]{8}{*}{ (Astler-Coller) } & & $(0.08-0.32)$ & & $(0.29-0.51)$ & \\
\hline & A & 0.53 & & 0.79 & \\
\hline & $\mathrm{B}$ & 0.79 & & 1.05 & \\
\hline & & $(0.19-1.84)$ & 0.028 & $(0.19-1.73)$ & 0.024 \\
\hline & $\mathrm{C}$ & 0.48 & $(\mathrm{~B}-\mathrm{C})$ & 0.60 & $(\mathrm{~B}-\mathrm{C})$ \\
\hline & & $(0-1.41)$ & & $(0.07-1.34)$ & \\
\hline & $\mathrm{D}$ & 1.65 & 0.027 & 1.93 & 0.017 \\
\hline & & $(0.83-2.71)$ & $(\mathrm{C}-\mathrm{D})$ & $(0.89-2.56)$ & $(\mathrm{C}-\mathrm{D})$ \\
\hline \multirow[t]{4}{*}{ Lymph nodes } & Positive & 0.55 & & 0.68 & \\
\hline & & $(0-2.71)$ & & $(0.08-2.56)$ & \\
\hline & Negative & 0.77 & 0.247 & 1.03 & 0.192 \\
\hline & & $(0.19-1.84)$ & & $(0.19-1.73)$ & \\
\hline \multirow[t]{6}{*}{ Differentiation } & Well & 1.14 & 0.070 & 1.19 & \\
\hline & & $(0.48-1.84)$ & & $(0.43-1.73)$ & \\
\hline & Moderately & 0.63 & 0.038 (well-mod) & 0.77 & \\
\hline & & $(0.09-2.71)$ & & $(0.08-2.56)$ & 0.261 \\
\hline & Poorly & 0.64 & 0.043 (well-poor) & 0.77 & \\
\hline & & $(0-0.96)$ & & $(0.43-1.32)$ & \\
\hline
\end{tabular}

Notes: $\mathrm{S}$ - Survivin, $\mathrm{N}$ - normal tissue, $\mathrm{Ca}$ - tumor tissue.

in moderately (median: $0.65 ; 0.49-1.16)$ compared to well-differentiated tumors (median: 0.97; 0.44-2.31) (Fig. 3B).

\subsection{Assessment of survivin snps $9386 C / T$ and $-31 G / C$ in $C R C$}

Regarding the $-31 \mathrm{G} / \mathrm{G}$ snp of the survivin gene, the $\mathrm{G}$ allele was noted more frequently than the $\mathrm{C}$ allele. Notably, 63 (38.6\%) patients were GG, 16 (9.8\%) were CC and 84 (51.6\%) were heterozygotes. More- over, in the healthy control group, $66(50 \%)$ were GG, $16(12.1 \%)$ were CC and 50 (37.9\%) were heterozygotes. Neither allele was associated with the gender or the primary site. However, the $\mathrm{C}$ allele appears to be associated with CRC. In fact, $101(61.9 \%)$ CRC patients carried the $\mathrm{C}$ allele, whereas in healthy controls, the percentage dropped to 50 (66 individuals) ( $p=0.04$ ). However, a larger number of cases is required to assess whether the $\mathrm{C}$ allele may predispose to CRC. Currently, the $\mathrm{CC}$ homozygotes may have a higher risk of developing cancer compared to GG individuals and the 

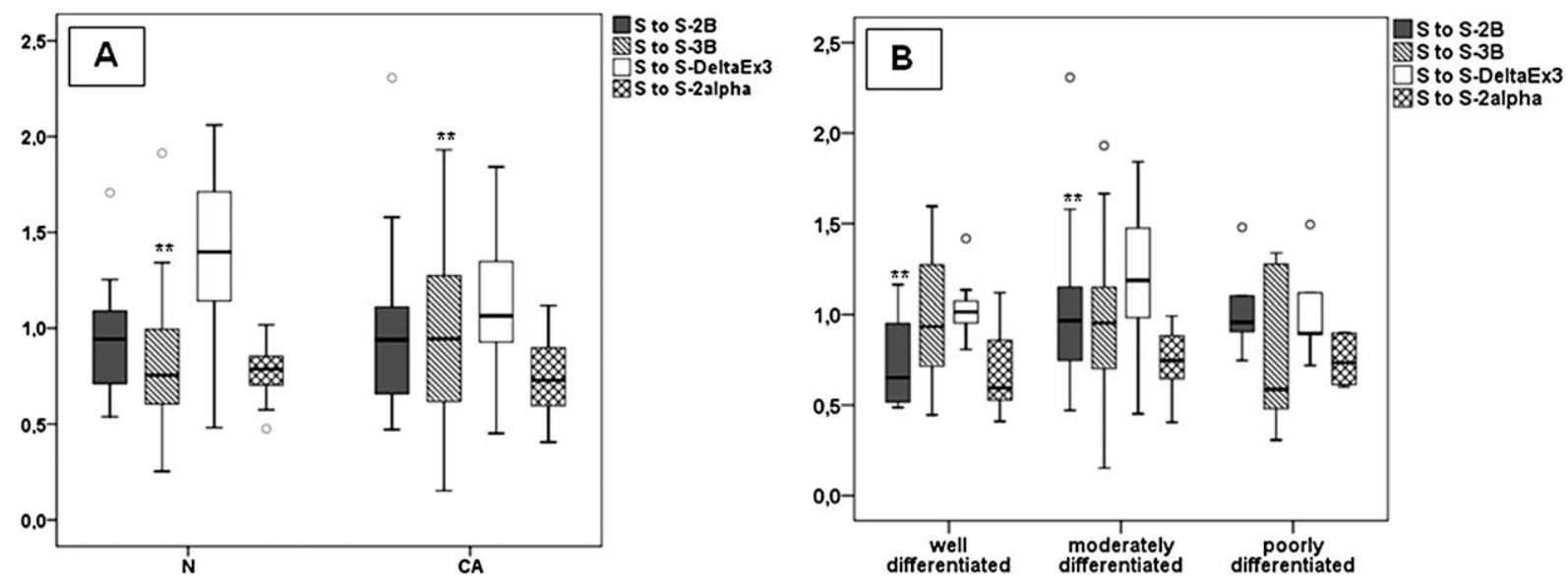

Fig. 3. The change of ratios of expression of the different variants in normal and neoplastic tissue and according to degree of differentiation. ** indicate differences significant to the 0.05 level.

heterozygotes (odds ratio 1.587, 95\% CI: 0.997-2.526, $p=0.051)$.

Regarding the $9386 \mathrm{C} / \mathrm{T}$ snp, which was genotyped in 42 cases for which fresh/frozen tissue was available, 2 cases were CC (4.8\%), 28 were CT (66.6\%) and 12 were TT $(28.6 \%)$.

\subsection{Relationships between survivin snp genotypes and splice variant expression}

Patients carrying the $\mathrm{C}$ allele at -31 had higher mRNA levels of the splice variants survivin, survivin$\Delta \mathrm{Ex} 3$, survivin-2B and survivin- $2 \alpha$ in neoplastic tissue compared to non-carriers $(p=0.056,0.003,0.022$, 0.022 , respectively) (Fig. 4). Interestingly, expression levels in normal tissue were independent of the -31 genotype (Fig. 4).

No association emerged between splice variant expression and the 9386C/T snp genotype with the exception of the ratios survivin to survivin- $2 \alpha$ and survivin to survivin-2B in neoplastic tissue. Notably, both of these ratios were lower in CC patients compared to $\mathrm{CT}$ and TT patients (survivin/survivin-2 $\alpha: p=$ 0.029 , median: 0.38 [0.33-0.44]; 0.85 [0.41-1.02]; 0.60 [0.41-0.69], respectively and survivin/survivin2B: $p=0.017$, median: 0.48 [0.44-0.52]; 0.95 [0.541.26]; 0.65 [0.47-0.94], respectively).

\subsection{Relationship between the $-31 G / C$ snp, disease progression and patient survival}

Since the $\mathrm{C}$ allele was more frequently observed in CRC patients and associated with higher levels of survivin expression in neoplastic tissue, the relationship between the $-31 \mathrm{G} / \mathrm{C}$ snp and relapse and survival was assessed. Neither allele was associated with increased risk of relapse or with the time to disease progression (data not shown). Surprisingly, however, the $\mathrm{C}$ allele was associated with improved overall survival (95\% CI; 95.074-118.126; $p=0.047$ ) (Fig. 5).

\subsection{Survivin protein expression and localization}

In normal colorectal mucosa survivin protein expression was nuclear and mainly confined to the crypt epithelium (Fig. 6). A significantly higher survivin expression was found in neoplastic tissue compared to normal tissue $(p<0.001)$. Moreover, while in normal tissue samples protein expression was exclusively located in the nucleus, in carcinomas cytoplasmic expression of survivin was also noted in 7 of 43 cases (16.28\%) (Table 5, Fig. 6). In carcinomas, nuclear survivin expression correlated with the primary site, with expression levels being higher in tumors of the right colon compared to tumors located in the left colon or the rectum $(p=0.004)$ (Table 5). There was no correlation between survivin mRNA and protein levels. Furthermore, survivin protein expression did not correlate either with the $-31 \mathrm{G} / \mathrm{C}$ or the $9386 \mathrm{C} / \mathrm{T}$ snp genotype or with any of the clinicopathological parameters analyzed.

\section{Discussion}

Survivin has attracted much attention in cancer research due to its involvement in the regulation of cell division and survival. Most studies of survivin in CRC have focused on protein expression and less is known about the expression of survivin splicing variants or 

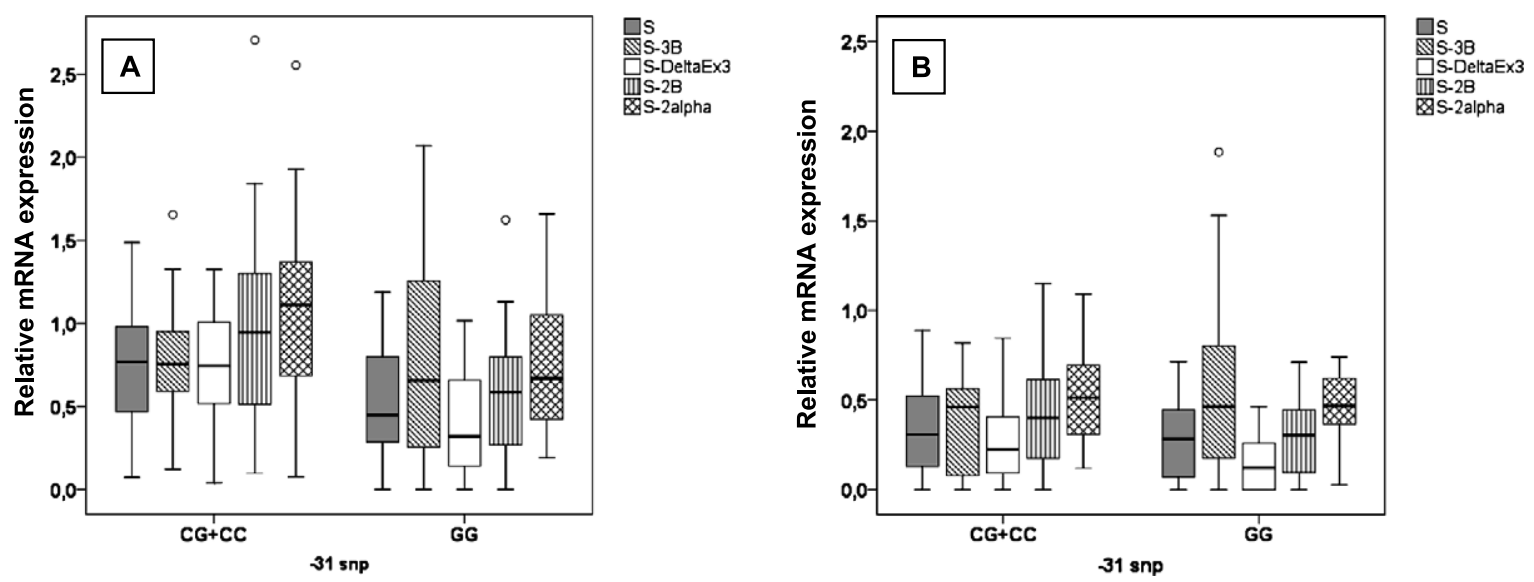

Fig. 4. Relationship between expression levels of survivin splice variants and -31 genotype. S - survivin, A - neoplastic tissue, B - normal tissue.

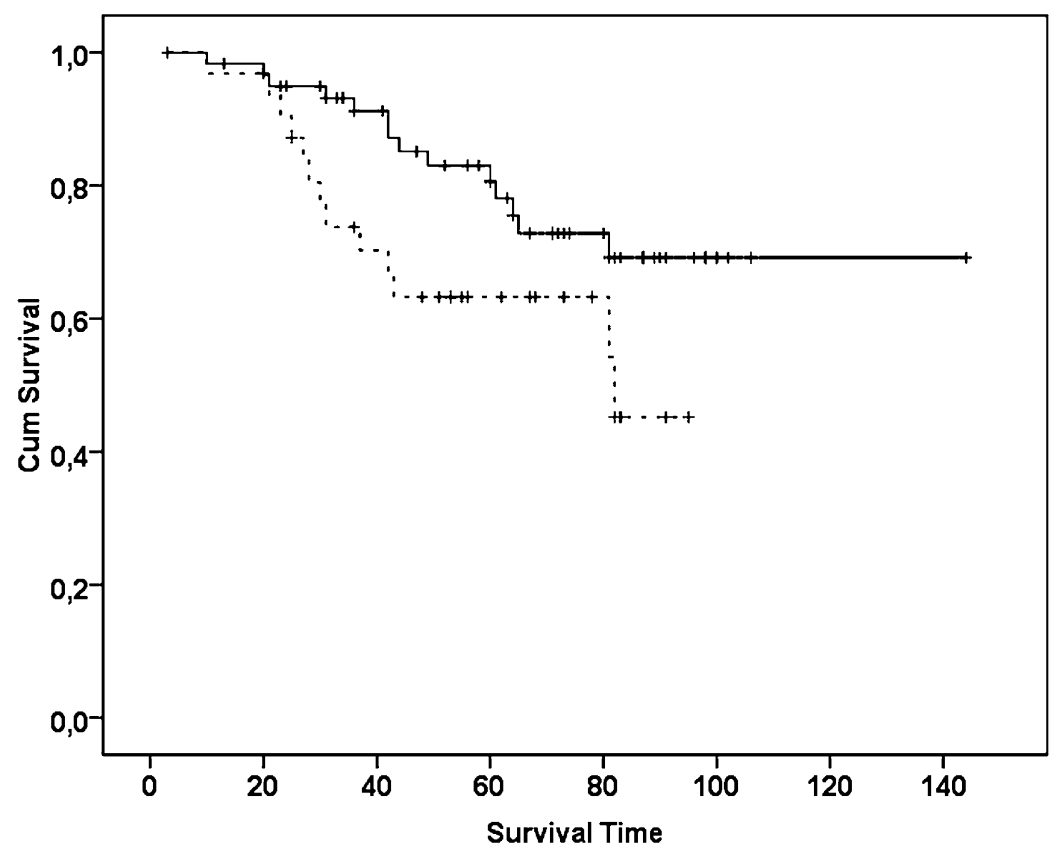

Fig. 5. Improved survival in the presence of the $-31 \mathrm{C}$ allele. Continuous and dotted lines represent the patients carrying the $\mathrm{C}$ allele and the $\mathrm{GG}$ homozygotes, respectively.

survivin gene polymorphisms in CRC. In the present study, the mRNA expression levels of the five known isoforms of survivin were assessed in matched normal and neoplastic colorectal tissue. Also survivin protein levels and survivin 9386C/T and $-31 \mathrm{G} / \mathrm{C}$ genetic polymorphisms were analysed. Our study provides evidence on the distinct significance of survivin splice variant expression and gene polymorphisms in human colorectal carcinogenesis

In agreement with previous reports, we have shown that mRNA expression of survivin splice variants was more frequent and significantly higher in neoplastic compared to normal tissue suggesting survivin involvement in colorectal carcinogenesis $[32,35]$. To the best of our knowledge this is the first report of splice variants survivin- $2 \alpha$ and survivin-3B expression in human CRC. Similarly to the findings of Suga et al., survivin expression did not correlate with gender and lymph node metastasis. However, survivin-2B mRNA levels were significantly higher in well differentiated tumors and survivin- $\Delta \mathrm{Ex} 3,-2 \mathrm{~B}$ and $-2 \alpha$ mRNA expression was significantly higher in stage $B$ than in stage $C$ pa- 


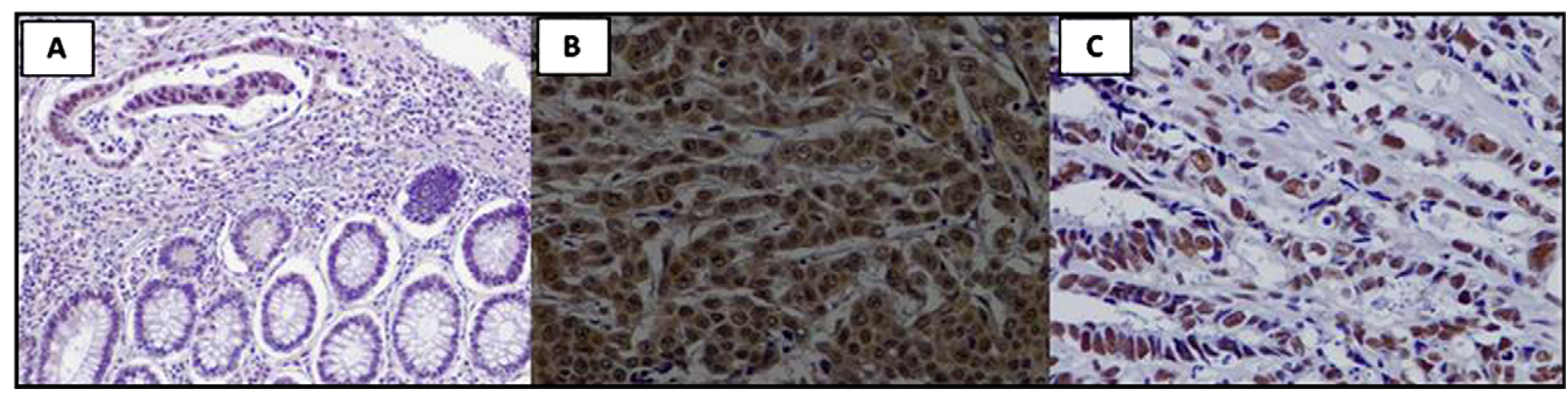

Fig. 6. Survivin protein expression by immunohistochemistry in colorectal carcinomas. (A) Significantly higher nuclear expression of survivin in cancerous tissue (upper part) compared to adjacent normal colonic crypts (lower part) $(\times 20)$. (B) Strong nuclear expression of survivin in a case of colorectal carcinoma $(\times 40)$. (C) A representative case showing both cytoplasmic and nuclear localization of survivin $(\times 40)$. $($ Colors are visible in the online version of the article; http://dx.doi.org/10.3233/ACP-CLO-2010-0537.)

tients indicating a correlation of specific splice variant expression with a less aggressive CRC phenotype. These findings are in agreement with the lack of an anti-apoptotic activity that characterize survivin$2 \mathrm{~B}$ and survivin- $2 \alpha$ isoforms but are unexpected for survivin- $\Delta \mathrm{Ex} 3$ that is known to promote cell survival $[5,23]$. It would be of interest to assess the expression of the survivin variants in the corresponding metastases and the circulating blood cells. It has been shown that in both cases, expression of molecules in key pathways including EGFR and TGF $\beta$ are often different between the primary tumor, the metastases and the circulating blood cells $[17,34]$.

To further address the significance of the specific survivin splice variant expression in CRC we assessed their ratio relative to survivin, since the relative abundance of these isofoms may be more significant than the presence of each isoform alone. In contrast to the mRNA levels, survivin to survivin- $\Delta \mathrm{Ex} 3$ and survivin$2 \alpha$ ratios showed no significant correlation with any of the clinicopathological parameters analyzed. However, survivin-2B levels were significantly higher relatively to survivin in well differentiated tumors. The later finding is consistent with the reduced anti-apoptotic activity of this isoform and also indicates that among the different splice variants survivin-2B is more likely to associate with favorable features of CRC. Unfortunately, the cohort of patients for whom fresh/frozen tissue was available for splice variant analysis had no sufficient time of follow up to allow survival analysis so as to assess the prognostic significance of the survivin isoforms. However, in further agreement with our findings, distinct significance of survivin specific splice variant expression has been reported in several tumor types [6]. It has been shown that survivin isoforms dimerize and this could partly constitute a control mechanism for the end action of survivin. Given the differential expression of splice variants, it appears to be more prudent to take into account ratios of expression rather than each isoform alone.

Of interest is the finding that both snps of the survivin gene correlated with survivin isoform mRNA expression levels or ratios in neoplastic but not in normal tissue, suggesting that these snps may influence the differential expression of survivin splice variants in colorectal carcinogenesis. Regarding the better studied $-31 \mathrm{G} / \mathrm{C}$ snp, this finding may suggest that repression through binding to the CDE/CHR element gains importance as a control mechanism of survivin expression in cancer, since other mechanisms involved in the regulation of survivin expression such as APC and P53 are often inactivated in neoplasia due to mutations [37, 38]. In agreement with the findings of Gazouli et al. we also showed a significantly higher frequency of the $\mathrm{C}$ allele in CRC patients compared to healthy controls suggesting a role of the $-31 \mathrm{G} / \mathrm{C}$ snp in colorectal carcinogenesis [8]. Nevertheless, it is possible that the $-31 \mathrm{G} / \mathrm{C}$ snp does not have a causative role but may simply feature a marker.

Notably we provided evidence that the presence of the $\mathrm{C}$ allele in $-31 \mathrm{G} / \mathrm{C}$ snp was associated with improved overall survival of CRC patients. Although an association of survivin $-31 \mathrm{G} / \mathrm{C}$ snp with increased risk of cancer development has been suggested by other reports, its prognostic significance in human CRC has not previously been addressed. Considering that the $-31 \mathrm{G} / \mathrm{C}$ snp correlated with splice variant expression in our tumor samples, this finding agrees with the association we found between isoform expression and favorable pathologic features, further indicating a complex most likely favorable prognostic role of survivin in human CRC. Although many reports state that increased levels of survivin correlate with colorectal cancer progression, liver metastasis $[7,18]$ and decreased 
Table 5

Survivin protein expression in neoplastic tissue; correlations with clinicopathological characteristics

\begin{tabular}{|c|c|c|c|c|c|c|c|c|c|c|c|c|}
\hline \multirow[t]{3}{*}{ Characteristic } & & \multicolumn{11}{|c|}{ Survivin protein expression } \\
\hline & & \multirow[t]{2}{*}{$N$} & \multicolumn{4}{|c|}{ Cytoplasmic } & \multirow[t]{2}{*}{$p$} & \multicolumn{4}{|c|}{ Nuclear } & \multirow[t]{2}{*}{$p$} \\
\hline & & & $\begin{array}{c}0 \\
n(\%)\end{array}$ & $\begin{array}{c}1 \\
n(\%)\end{array}$ & $\begin{array}{c}2 \\
n(\%)\end{array}$ & $\begin{array}{c}3 \\
n(\%)\end{array}$ & & $\begin{array}{c}0 \\
n(\%)\end{array}$ & $\begin{array}{c}1 \\
n(\%)\end{array}$ & $\begin{array}{c}2 \\
n(\%)\end{array}$ & $\begin{array}{c}3 \\
n(\%)\end{array}$ & \\
\hline Tissue & Neoplastic & 43 & $\begin{array}{c}35 \\
(81.4)\end{array}$ & $\begin{array}{c}6 \\
(14)\end{array}$ & $\begin{array}{c}2 \\
(4.7)\end{array}$ & $\begin{array}{c}0 \\
(0)\end{array}$ & & $\begin{array}{c}1 \\
(2.3)\end{array}$ & $\begin{array}{c}1 \\
(2.3)\end{array}$ & $\begin{array}{c}19 \\
(44.2)\end{array}$ & $\begin{array}{c}22 \\
(51.2)\end{array}$ & \\
\hline \multirow[t]{2}{*}{ Gender } & Male & 28 & $\begin{array}{c}23 \\
(82.1)\end{array}$ & $\begin{array}{c}4 \\
(14.3)\end{array}$ & $\begin{array}{c}1 \\
(3.5)\end{array}$ & $\begin{array}{c}0 \\
(0)\end{array}$ & & $\begin{array}{c}1 \\
(3.5)\end{array}$ & $\begin{array}{c}1 \\
(3.5)\end{array}$ & $\begin{array}{c}13 \\
(46.4)\end{array}$ & $\begin{array}{c}13 \\
(46.4)\end{array}$ & \\
\hline & Female & 15 & $\begin{array}{c}12 \\
(80)\end{array}$ & $\begin{array}{c}2 \\
(13.3)\end{array}$ & $\begin{array}{c}1 \\
(6.7)\end{array}$ & $\begin{array}{c}0 \\
(0)\end{array}$ & 0.899 & $\begin{array}{c}0 \\
(0)\end{array}$ & $\begin{array}{c}0 \\
(0)\end{array}$ & $\begin{array}{c}6 \\
(40)\end{array}$ & $\begin{array}{c}9 \\
(60)\end{array}$ & 0.645 \\
\hline \multirow[t]{3}{*}{ Primary site } & Right colon & 12 & $\begin{array}{c}6 \\
(50)\end{array}$ & $\begin{array}{c}5 \\
(41.7)\end{array}$ & $\begin{array}{c}1 \\
(8.3)\end{array}$ & $\begin{array}{c}0 \\
(0)\end{array}$ & 0.012 & $\begin{array}{c}1 \\
(8.3)\end{array}$ & $\begin{array}{c}0 \\
(0)\end{array}$ & $\begin{array}{c}5 \\
(41.7)\end{array}$ & $\begin{array}{c}6 \\
(50)\end{array}$ & 0.251 \\
\hline & $\begin{array}{l}\text { Left colon } \\
\text { and sigmoid }\end{array}$ & 15 & $\begin{array}{c}13 \\
(86.7)\end{array}$ & $\begin{array}{c}1 \\
(6.7)\end{array}$ & $\begin{array}{c}1 \\
(6.7)\end{array}$ & $\begin{array}{c}0 \\
(0)\end{array}$ & & $\begin{array}{c}0 \\
(0)\end{array}$ & $\begin{array}{c}1 \\
(6.7)\end{array}$ & $\begin{array}{c}4 \\
(26.7)\end{array}$ & $\begin{array}{c}10 \\
(66.7)\end{array}$ & \\
\hline & Rectum & 16 & $\begin{array}{c}16 \\
(100)\end{array}$ & $\begin{array}{c}0 \\
(0)\end{array}$ & $\begin{array}{c}0 \\
(0)\end{array}$ & $\begin{array}{c}0 \\
(0)\end{array}$ & & $\begin{array}{c}0 \\
(0)\end{array}$ & $\begin{array}{c}0 \\
(0)\end{array}$ & $\begin{array}{c}10 \\
(62.5)\end{array}$ & $\begin{array}{c}6 \\
(37.5)\end{array}$ & \\
\hline \multirow[t]{5}{*}{$\begin{array}{l}\text { Stage } \\
\text { (Astler-Coller) }\end{array}$} & In situ & 4 & $\begin{array}{c}3 \\
(75)\end{array}$ & $\begin{array}{c}0 \\
(0)\end{array}$ & $\begin{array}{c}1 \\
(25)\end{array}$ & $\begin{array}{c}0 \\
(0)\end{array}$ & 0.625 & $\begin{array}{c}1 \\
(25)\end{array}$ & $\begin{array}{c}0 \\
(0)\end{array}$ & $\begin{array}{c}2 \\
(50)\end{array}$ & $\begin{array}{c}1 \\
(25)\end{array}$ & 0.170 \\
\hline & A & 1 & $\begin{array}{c}1 \\
(100)\end{array}$ & $\begin{array}{c}0 \\
(0)\end{array}$ & $\begin{array}{c}0 \\
(0)\end{array}$ & $\begin{array}{c}0 \\
(0)\end{array}$ & & $\begin{array}{c}0 \\
(0)\end{array}$ & $\begin{array}{c}0 \\
(0)\end{array}$ & $\begin{array}{c}1 \\
(100)\end{array}$ & $\begin{array}{c}0 \\
(0)\end{array}$ & \\
\hline & $\mathrm{B}$ & 21 & $\begin{array}{c}16 \\
(64)\end{array}$ & $\begin{array}{c}4 \\
(19)\end{array}$ & $\begin{array}{c}1 \\
(4.8)\end{array}$ & $\begin{array}{c}0 \\
(0)\end{array}$ & & $\begin{array}{c}0 \\
(0)\end{array}$ & $\begin{array}{c}1 \\
(4.8)\end{array}$ & $\begin{array}{c}8 \\
(38.1)\end{array}$ & $\begin{array}{c}12 \\
(57.1)\end{array}$ & \\
\hline & $\mathrm{C}$ & 14 & $\begin{array}{c}12 \\
(85.8)\end{array}$ & $\begin{array}{c}2 \\
(14.3)\end{array}$ & $\begin{array}{c}0 \\
(0)\end{array}$ & $\begin{array}{c}0 \\
(0)\end{array}$ & & $\begin{array}{c}0 \\
(0)\end{array}$ & $\begin{array}{c}0 \\
(0)\end{array}$ & $\begin{array}{c}8 \\
(57.1)\end{array}$ & $\begin{array}{c}6 \\
(42.9)\end{array}$ & \\
\hline & $\mathrm{D}$ & 3 & $\begin{array}{c}3 \\
(100)\end{array}$ & $\begin{array}{c}0 \\
(0)\end{array}$ & $\begin{array}{c}0 \\
(0)\end{array}$ & $\begin{array}{c}0 \\
(0)\end{array}$ & & $\begin{array}{c}0 \\
(0)\end{array}$ & $\begin{array}{c}0 \\
(0)\end{array}$ & $\begin{array}{c}0 \\
(0)\end{array}$ & $\begin{array}{c}3 \\
(100)\end{array}$ & \\
\hline \multirow[t]{2}{*}{ Lymph nodes } & Positive & 17 & $\begin{array}{c}15 \\
(88.2)\end{array}$ & $\begin{array}{c}2 \\
(11.8)\end{array}$ & $\begin{array}{c}0 \\
(0)\end{array}$ & $\begin{array}{c}0 \\
(0)\end{array}$ & & $\begin{array}{c}0 \\
(0)\end{array}$ & $\begin{array}{c}0 \\
(0)\end{array}$ & $\begin{array}{c}8 \\
(47.1)\end{array}$ & $\begin{array}{c}9 \\
(53)\end{array}$ & \\
\hline & Negative & 26 & $\begin{array}{c}20 \\
(77)\end{array}$ & $\begin{array}{c}4 \\
(15.4)\end{array}$ & $\begin{array}{c}2 \\
(7.7)\end{array}$ & $\begin{array}{c}0 \\
(0)\end{array}$ & 0.457 & $\begin{array}{c}1 \\
(3.9)\end{array}$ & $\begin{array}{c}1 \\
(3.9)\end{array}$ & $\begin{array}{c}11 \\
(42.3)\end{array}$ & $\begin{array}{c}13 \\
(50)\end{array}$ & 0.838 \\
\hline \multirow[t]{3}{*}{ Differentiation } & Well & 8 & $\begin{array}{c}8 \\
(100)\end{array}$ & $\begin{array}{c}0 \\
(0)\end{array}$ & $\begin{array}{c}0 \\
(0)\end{array}$ & $\begin{array}{c}0 \\
(0)\end{array}$ & 0.593 & $\begin{array}{c}0 \\
(0)\end{array}$ & $\begin{array}{c}1 \\
(12.5)\end{array}$ & $\begin{array}{c}3 \\
(37.5)\end{array}$ & $\begin{array}{c}4 \\
(50)\end{array}$ & 0.505 \\
\hline & Moderate & 24 & $\begin{array}{c}18 \\
(75)\end{array}$ & $\begin{array}{c}5 \\
(20.8)\end{array}$ & $\begin{array}{c}1 \\
(14.3)\end{array}$ & $\begin{array}{c}0 \\
(0)\end{array}$ & & $\begin{array}{c}0 \\
(0)\end{array}$ & $\begin{array}{c}0 \\
(0)\end{array}$ & $\begin{array}{c}10 \\
(41.7)\end{array}$ & $\begin{array}{c}14 \\
(58.3)\end{array}$ & \\
\hline & Poor & 7 & $\begin{array}{c}6 \\
(85.8)\end{array}$ & $\begin{array}{c}1 \\
(4.2)\end{array}$ & $\begin{array}{c}0 \\
(0)\end{array}$ & $\begin{array}{c}0 \\
(0)\end{array}$ & & $\begin{array}{c}0 \\
(0)\end{array}$ & $\begin{array}{c}0 \\
(0)\end{array}$ & $\begin{array}{c}4 \\
(57.1)\end{array}$ & $\begin{array}{c}3 \\
(42.9)\end{array}$ & \\
\hline
\end{tabular}

survival, contradictory observations are also available [11]. In some studies different splice variants appear to correlate differently to survival while in others survivin levels were unrelated to survival in CRC cases $[11,31]$. However, it is also likely that the $-31 \mathrm{G} / \mathrm{C}$ snp may simply be a favorable prognostic marker in CRC irrespectively of its possible effect on survivin expression.

Contrary to mRNA levels, protein levels were unrelated to any of the clinicopathological parameters with the exception of the primary site. This may reflect the genetic differences noted in the different anatomical sites which may be accounted for by their different embryological origin [16]. The antibody used in the immunohistochemical analysis was not able to differentiate between different isoforms and, therefore, it is not clear whether the differences observed at the mRNA levels between stages and grades are reflected on the protein level or not. However, the contribution of posttranscriptional regulatory mechanisms in the regulation of survivin expression may account for the lack of correlation between protein and mRNA expression and 
is in agreement with the findings of Kannangai et al. although contradictory reports have also been published $[12,19,30]$.

Protein expression was detected exclusively in the nucleus in normal tissue, whereas both nuclear and cytoplasmic expression, with the predominance of nuclear staining, was noted in CRCs. A cytoplasmic expression of survivin has previously been demonstrated for colorectal carcinomas $[7,13]$. The difference in localization patterns between studies may be due to the different antibodies used for the detection of survivin, targeting different areas of the protein and therefore reacting with different isoforms. It is known that survivin exists in two subcellular pools consistent with its function in cell division (nucleus) and cell viability (cytoplasm) as well as the presence of the different isoforms which have distinct cellular localizations [22]. The nuclear immunoreactivity has been associated with significantly higher proliferating index in hepatocellular carcinomas suggesting a predominant role of survivin in promoting cell division in these tumors [27,28]. The cellular localization pattern of survivin in our tumor samples suggests that survivin probably exerts both cell division-promoting and anti-apoptotic functions in colorectal carcinogenesis.

In conclusion, mRNA expression of all 5 survivin splice variants as well as survivin protein expression was elevated in colorectal carcinomas compared to normal tissue supporting a role of survivin in colorectal carcinogenesis. Specific survivin splice variant expression differentially correlated with pathologic tumor parameters. Furthermore, both the $-31 \mathrm{G} / \mathrm{C}$ snp and the $9386 \mathrm{C} / \mathrm{T}$ snp correlated with splice variant levels or their ratios in colorectal carcinomas while the $-31 \mathrm{G} / \mathrm{C}$ snp may be related to $\mathrm{CRC}$ development and overall survival.

\section{References}

[1] G. Ambrosini, C. Adida and D.C. Altieri, A novel antiapoptosis gene, survivin, expressed in cancer and lymphoma, Nat. Med. 3 (1997), 917-921.

[2] A.G. Antonacopoulou, P.D. Grivas, L. Skarlas, M. Kalofonos, C.D. Scopa and H.P. Kalofonos, POLR2F, ATP6V0A1 and PRNP expression in colorectal cancer: new molecules with prognostic significance?, Anticancer Res. 28 (2008), 12211227.

[3] A. Badran, A. Yoshida, K. Ishikawa, T. Goi, A. Yamaguchi, T. Ueda and M. Inuzuka, Identification of a novel splice variant of the human anti-apoptopsis gene survivin, Biochem. Biophys. Res. Commun. 314 (2004), 902-907.
[4] A.A. Borbely, M. Murvai, K. Szarka, J. Konya, L. Gergely, Z. Hernadi and G. Veress, Survivin promoter polymorphism and cervical carcinogenesis, J. Clin. Pathol. 60 (2007), 303306.

[5] H. Caldas, L.E. Honsey and R.A. Altura, Survivin 2alpha: a novel Survivin splice variant expressed in human malignancies, Mol. Cancer 4 (2005), 11.

[6] S. De Maria, G. Pannone, P. Bufo, A. Santoro, R. Serpico, S. Metafora, C. Rubini, D. Pasquali, S.M. Papagerakis, S. Staibano, G. De Rosa, E. Farina, M. Emanuelli, A. Santarelli, M.A. Mariggio, L. Lo Russo and L. Lo Muzio, Survivin gene-expression and splicing isoforms in oral squamous cell carcinoma, J. Cancer Res. Clin. Oncol. 135 (2009), 107-116.

[7] L.F. Fan, W.G. Dong, C.Q. Jiang, Q. Qian and Q.F. Yu, Role of Hypoxia-inducible factor-1 alpha and Survivin in colorectal carcinoma progression, Int. J. Colorectal Dis. 23 (2008), 1057-1064.

[8] M. Gazouli, N. Tzanakis, G. Rallis, G. Theodoropoulos, I. Papaconstantinou, A. Kostakis, N.P. Anagnou and N. Nikiteas, Survivin $-31 \mathrm{G} / \mathrm{C}$ promoter polymorphism and sporadic colorectal cancer, Int. J. Colorectal Dis. 24 (2009), 145-150.

[9] P.D. Grivas, A. Antonacopoulou, V. Tzelepi, G. SotiropoulouBonikou, Z. Kefalopoulou, A.G. Papavassiliou and H. Kalofonos, HER-3 in colorectal tumourigenesis: from mRNA levels through protein status to clinicopathologic relationships, Eur. J. Cancer 43 (2007), 2602-2611.

[10] J.S. Jang, K.M. Kim, K.H. Kang, J.E. Choi, W.K. Lee, C.H. Kim, Y.M. Kang, S. Kam, I.S. Kim, J.E. Jun, T.H. Jung and J.Y. Park, Polymorphisms in the survivin gene and the risk of lung cancer, Lung Cancer 60 (2008), 31-39.

[11] J.G. Kalliakmanis, C. Kouvidou, C. Latoufis, G. Kouvatseas, D. Anagnostakis, G. Papatheodoridis, J. Koskinas and A. Archimandritis, Survivin expression in colorectal carcinomas: correlations with clinicopathological parameters and survival, Dig. Dis. Sci., Online first (2009).

[12] R. Kannangai, J. Wang, Q.Z. Liu, F. Sahin and M. Torbenson, Survivin overexpression in hepatocellular carcinoma is associated with p53 dysregulation, Int. J. Gastrointest Cancer $\mathbf{3 5}$ (2005), 53-60.

[13] H. Kawasaki, D.C. Altieri, C.D. Lu, M. Toyoda, T. Tenjo and N. Tanigawa, Inhibition of apoptosis by survivin predicts shorter survival rates in colorectal cancer, Cancer Res. 58 (1998), 5071-5074.

[14] H. Kawasaki, M. Toyoda, H. Shinohara, J. Okuda, I. Watanabe, T. Yamamoto, K. Tanaka, T. Tenjo and N. Tanigawa, Expression of survivin correlates with apoptosis, proliferation, and angiogenesis during human colorectal tumorigenesis, Cancer 91 (2001), 2026-2032.

[15] S.K. Knauer, C. Bier, P. Schlag, J. Fritzmann, W. Dietmaier, F. Rodel, L. Klein-Hitpass, A.F. Kovacs, C. Doring, M.L. Hansmann, W.K. Hofmann, M. Kunkel, C. Brochhausen, K. Engels, B.M. Lippert, W. Mann and R.H. Stauber, The survivin isoform survivin-3B is cytoprotective and can function as a chromosomal passenger complex protein, Cell Cycle 6 (2007), 1502-1509.

[16] K. Komuro, M. Tada, E. Tamoto, A. Kawakami, A. Matsunaga, K. Teramoto, G. Shindoh, M. Takada, K. Murakawa, M. Kanai, N. Kobayashi, Y. Fujiwara, N. Nishimura, J. Hamada, A. Ishizu, H. Ikeda, S. Kondo, H. Katoh, T. Moriuchi and T. Yoshiki, Right- and left-sided colorectal cancers 
display distinct expression profiles and the anatomical stratification allows a high accuracy prediction of lymph node metastasis, J. Surg. Res. 124 (2005), 216-224.

[17] S. Lankiewicz, E. Rother, S. Zimmermann, C. Hollmann, F. Korangy and T.F. Greten, Tumour-associated transcripts and EGFR deletion variants in colorectal cancer in primary tumour, metastases and circulating tumour cells, Cell Oncol. 30 (2008), 463-471.

[18] S. Lassmann, L. Tang, M. Capanu, T. Brabletz, A. Schopflin, A. Zur Hausen, M. Gonen, N. Kemeny, J. Shia, D. Klimstra and M. Werner, Predictive molecular markers for colorectal cancer patients with resected liver metastasis and adjuvant chemotherapy, Gastroenterology 133 (2007), 1831-1839.

[19] F. Li, Survivin study: what is the next wave?, J. Cell Physiol. 197 (2003), 8-29.

[20] F. Li, G. Ambrosini, E.Y. Chu, J. Plescia, S. Tognin, P.C. Marchisio and D.C. Altieri, Control of apoptosis and mitotic spindle checkpoint by survivin, Nature 396 (1998), 580-584.

[21] F. Li and X. Ling, Survivin study: an update of "what is the next wave"?, J. Cell Physiol. 208 (2006), 476-486.

[22] F. Li, J. Yang, N. Ramnath, M.M. Javle and D. Tan, Nuclear or cytoplasmic expression of survivin: what is the significance?, Int. J. Cancer 114 (2005), 509-512.

[23] C. Mahotka, M. Wenzel, E. Springer, H.E. Gabbert and C.D. Gerharz, Survivin-deltaEx3 and survivin-2B: two novel splice variants of the apoptosis inhibitor survivin with different antiapoptotic properties, Cancer Res. 59 (1999), 6097-6102.

[24] W.H. Majoros and U. Ohler, Spatial preferences of microRNA targets in $3^{\prime}$ untranslated regions, BMC Genomics 8 (2007), 152

[25] W.E. Mesker, G.J. Liefers, J.M. Junggeburt, G.W. van Pelt, P. Alberici, P.J. Kuppen, N.F. Miranda, K.A. van Leeuwen, H. Morreau, K. Szuhai, R.A. Tollenaar and H.J. Tanke, Presence of a high amount of stroma and downregulation of SMAD4 predict for worse survival for stage I-II colon cancer patients, Cell Oncol. 31 (2009), 169-178.

[26] M. Monzo, R. Rosell, E. Felip, J. Astudillo, J.J. Sanchez, J. Maestre, C. Martin, A. Font, A. Barnadas and A. Abad, A novel anti-apoptosis gene: Re-expression of survivin messenger RNA as a prognosis marker in non-small-cell lung cancers, J. Clin. Oncol. 17 (1999), 2100-2104.

[27] W.S. Moon and A.S. Tarnawski, Nuclear translocation of survivin in hepatocellular carcinoma: a key to cancer cell growth?, Hum. Pathol. 34 (2003), 1119-1126.
[28] S. Peroukides, V. Bravou, A. Alexopoulos, J. Varakis, H. Kalofonos and H. Papadaki, Survivin overexpression in HCC and liver cirrhosis differentially correlates with p-STAT3 and Ecadherin, Histol. Histopathol. 25 (2010), 299-307.

[29] S. Rozen and H. Skaletsky, Primer3 on the WWW for general users and for biologist programmers, Methods Mol. Biol. 132 (2000), 365-386.

[30] B. Ryan, N. O'Donovan, B. Browne, C. O'Shea, J. Crown, A.D. Hill, E. McDermott, N. O'Higgins and M.J. Duffy, Expression of survivin and its splice variants survivin-2B and survivin-DeltaEx3 in breast cancer, Br. J. Cancer 92 (2005), 120-124.

[31] P.N. Span, V.C. Tjan-Heijnen, J.J. Heuvel, J.B. de Kok, J.A. Foekens and F.C. Sweep, Do the survivin (BIRC5) splice variants modulate or add to the prognostic value of total survivin in breast cancer?, Clin. Chem. 52 (2006), 1693-1700.

[32] K. Suga, T. Yamamoto, Y. Yamada, S. Miyatake, T. Nakagawa and N. Tanigawa, Correlation between transcriptional expression of survivin isoforms and clinicopathological findings in human colorectal carcinomas, Oncol. Rep. 13 (2005), 891897.

[33] K. Tanaka, S. Iwamoto, G. Gon, T. Nohara, M. Iwamoto and N. Tanigawa, Expression of survivin and its relationship to loss of apoptosis in breast carcinomas, Clin. Cancer Res. 6 (2000), $127-134$.

[34] L.M. Veenendaal, O. Kranenburg, N. Smakman, A. Klomp, I.H. Borel Rinkes, P.J. van Diest, Differential Notch and TGFbeta signaling in primary colorectal tumors and their corresponding metastases, Cell Oncol. 30 (2008), 1-11.

[35] F. Vegran, R. Boidot, C. Oudin, J.M. Riedinger and S. LizardNacol, Distinct expression of Survivin splice variants in breast carcinomas, Int. J. Oncol. 27 (2005), 1151-1157.

[36] Y. Xu, F. Fang, G. Ludewig, G. Jones and D. Jones, A mutation found in the promoter region of the human survivin gene is correlated to overexpression of survivin in cancer cells, DNA Cell Biol. 23 (2004), 527-537.

[37] T. Zhang, T. Otevrel, Z. Gao, Z. Gao, S.M. Ehrlich, J.Z. Fields and B.M. Boman, Evidence that APC regulates survivin expression: a possible mechanism contributing to the stem cell origin of colon cancer, Cancer Res. 61 (2001), 8664-8667.

[38] N. Zhu, L. Gu, H.W. Findley, F. Li and M. Zhou, An alternatively spliced survivin variant is positively regulated by p 53 and sensitizes leukemia cells to chemotherapy, Oncogene $\mathbf{2 3}$ (2004), 7545-7551. 


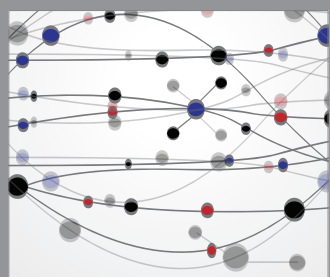

The Scientific World Journal
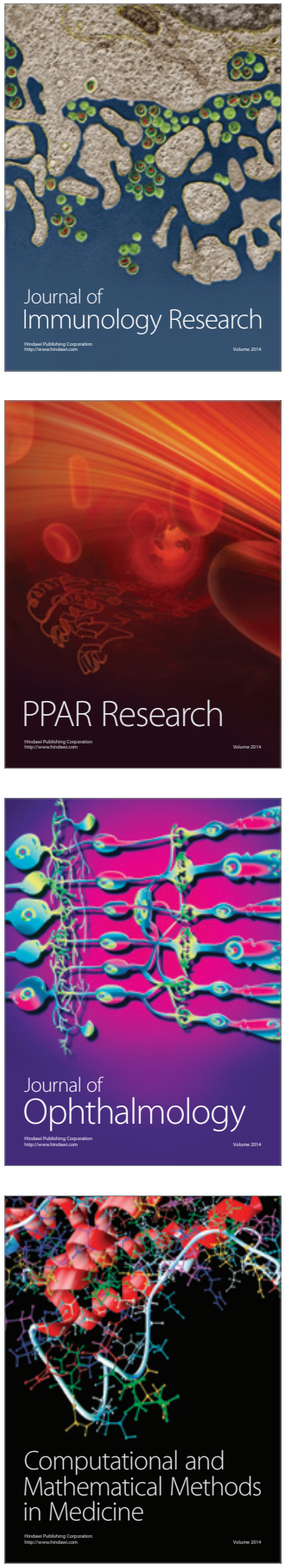

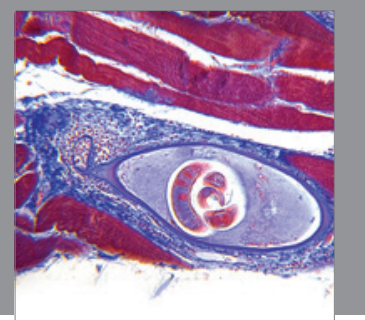

Gastroenterology

Research and Practice
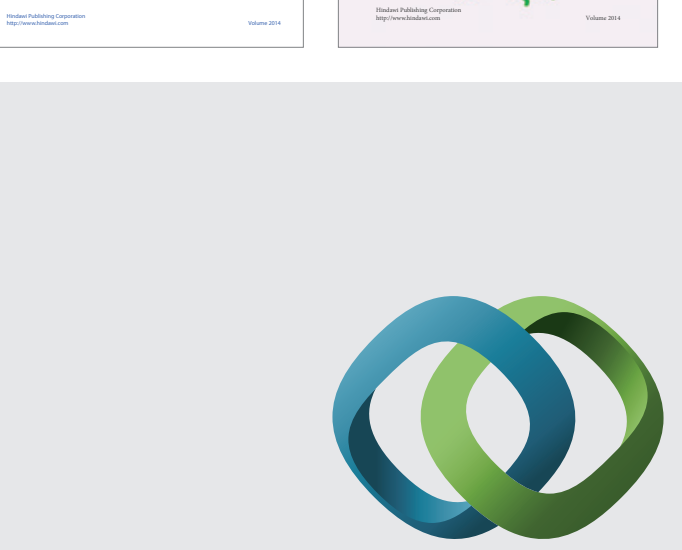

\section{Hindawi}

Submit your manuscripts at

http://www.hindawi.com
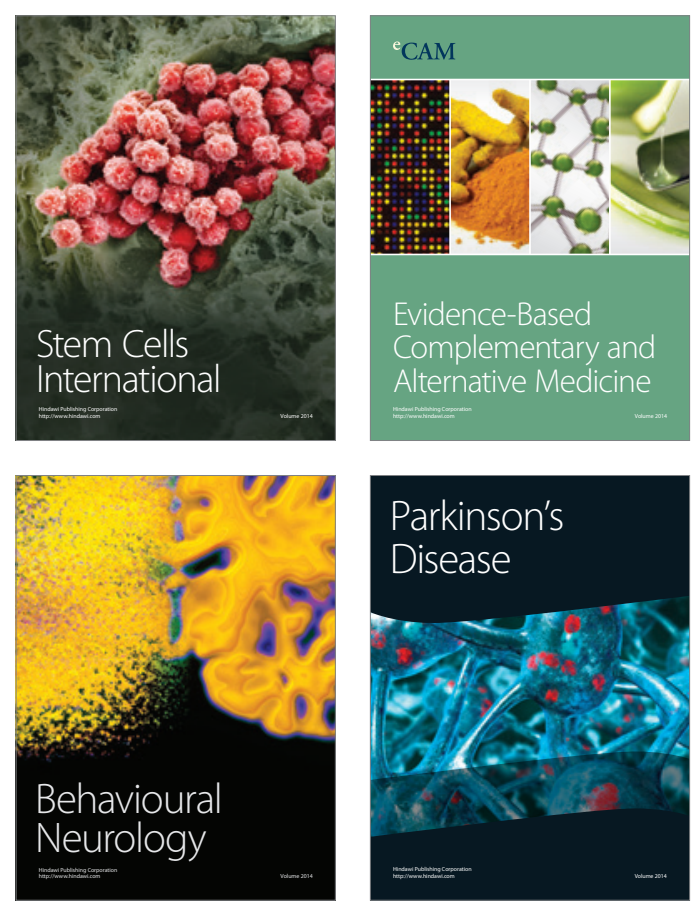

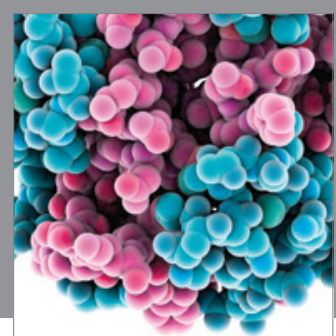

Journal of
Diabetes Research

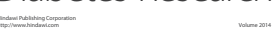

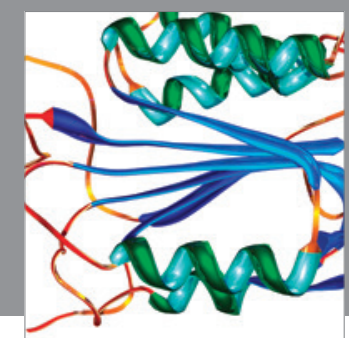

Disease Markers
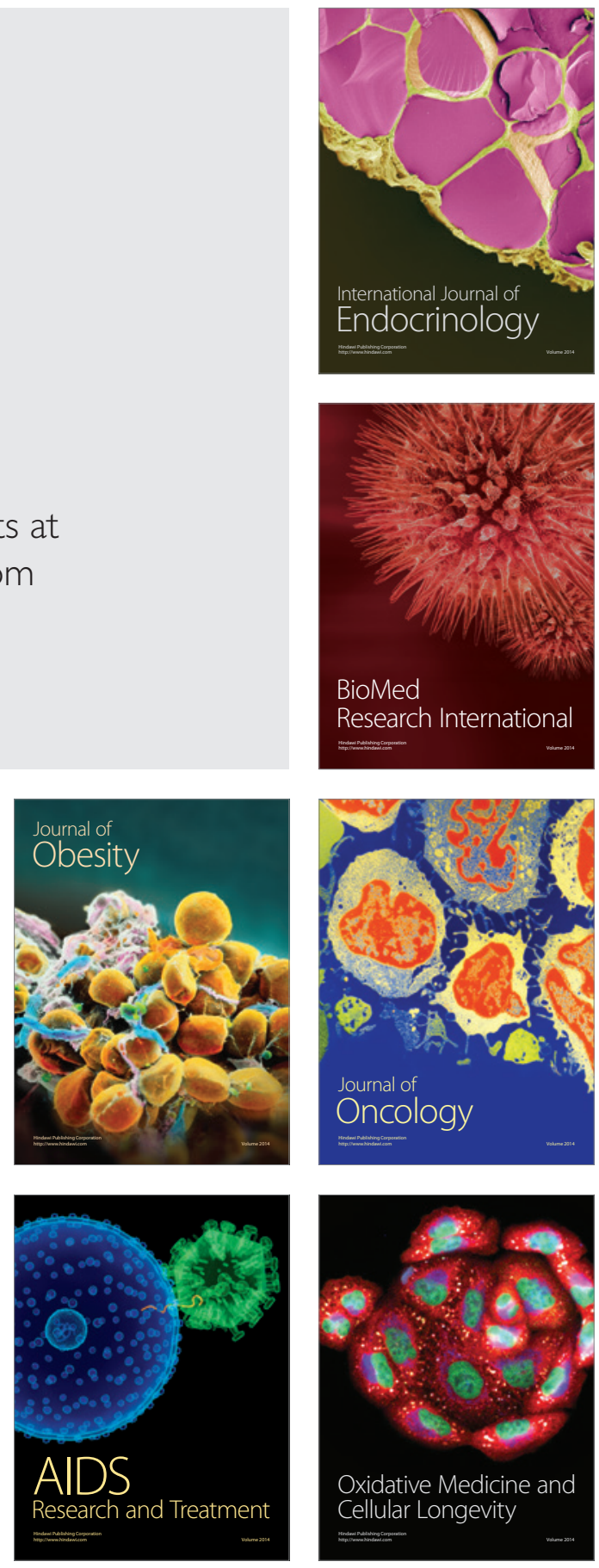